\title{
Pollinators and floral visitors of two orchids in a protected natural area in Tuxpan, Veracruz
}

\section{Polinizadores y visitantes florales de dos orquídeas en un área natural protegida en Tuxpan, Veracruz}

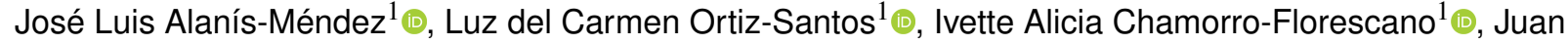 \\ Manuel Pech Canché ${ }^{[0,}$, Francisco Limón ${ }^{1 *}$ (D) \\ ${ }^{1}$ Facultad de Ciencias Biológicas y Agropecuarias, Universidad Veracruzana. Km. 7.5 Carretera Tuxpan-Tampico, CP. 92895. Tuxpan, \\ Veracruz, México. \\ *Corresponding author: flimon@uv.mx
}

Scientific note received: July 18, 2018 accepted: February 11, 2019

\begin{abstract}
Floral visitors, particularly pollinators, are important during the life cycle of many orchids. However, despite their biological importance, this information is still unknown in many species, particularly those in mangrove forests. The aim of this research was to study the floral visitors, as well as the pollinators, of the two orchid species Myrmecophila grandiflora and Brassavola nodosa, in a protected natural area with mangrove (RAMSAR), in Tuxpan, Veracruz, Mexico. Ants of different genera were the floral visitors of $M$. grandiflora, its pollinator is the carpenter bee, Xylocopa nautlana. In B. nodosa, were observed mosquitoes and ladybugs as floral visitors, the pollinator could not be registered, but it is possible that it is a species of moth (Scopula sp.). Finally, this study provides field information about floral visitors and pollinators in two orchid species in mangrove ecosystems and the evidence for pollination.
\end{abstract}

Key words: Epiphytes, Orchidaceae, RAMSAR, Schomburgkia, Xylocopa.

RESUMEN. Los visitantes florales, particularmente los polinizadores, son importantes durante el ciclo de vida de muchas orquídeas. Sin embargo, a pesar de su importancia biológica, esta información permanece desconocida para muchas especies, particularmente en ecosistemas de manglar. El objetivo de esta investigación, fue conocer los visitantes florales, así como polinizadores de dos especies de orquídeas Myrmecophila grandiflora y Brassavola nodosa en un área natural protegida con manglar (RAMSAR), en Tuxpan, Veracruz, México. Hormigas de diferentes géneros fueron los principales visitantes de M. grandiflora, su polinizador es la abeja carpintero Xylocopa nautlana. En B. nodosa, se observaron mosquitos y catarinas como visitantes florales. Este estudio provee información de campo acerca de los visitantes florales en dos especies de orquídeas en ecosistemas de manglar y la evidencia para la polinización.

Palabras clave: Epífitas, Orchidaceae, RAMSAR, Schomburgkia, Xylocopa.

\section{INTRODUCTION}

Plants interact with numerous species from taxonomically diverse groups (Herrera 1987, Horvitz and Schemske 1990). Pollination is one of the main reasons, and it is a fundamental requirement for the reproductive success of 80 to $90 \%$ of the flowering plants and up to $97 \%$ of the orchids (Schiestl 2005, Pellegrino et al. 2010). In Mexico, orchids (Orchidaceae) occupy the third place in taxonomic diversity of vascular plants and it is estimated that around
$40 \%$ of them are endemic (Hágsater et al. 1996, 2005). Their highest diversity is concentrated in three types of vegetation: tropical evergreen forest, temperate oak forests and tropical montane cloud forest (García-Cruz and Sosa 2011). On the other hand, ecosystems such as mangroves, have received less attention; these are important because of their high diversity of biological interactions and ecological importance (Basáñez 2005, Lee et al. 2014). Therefore, it is essential to integrate the knowledge of orchids into these ecosystems, as well as the species they 
interact with, pollinators and floral visitors.

In a protected natural area of northern Veracruz (RAMSAR 2016), we studied two orchid species associated with mangrove forests: Brassavola nodosa and Myrmecophila grandiflora (Ames and Correll 1985, Carnevali et al. 2001, Carnevali 2009). In both cases, their pollinators are unknown. Accordingly, the objectives of the present study were (1) to document associated phorophyte species with the orchids studied in a natural protected area; (2) to identify the pollinators and the floral visitors of the orchids in the mentioned natural protected area, and (3) to determine the type of pollination.

\section{MATERIALS AND METHODS}

\section{Study area}

The RAMSAR 1602 is a protected natural area located in the municipality of Tuxpan, in the north of the state of Veracruz, Mexico (Figure 1). Its average altitude is $14 \mathrm{~m}$, the climate is warm-subhumid with rains in winter, and the average annual temperature is $24.1{ }^{\circ} \mathrm{C}$ (INEGI 2010). It is listed among the wetlands of global conservation priority (RAMSAR 2016), and is one of the better conserved within the Biogeographical Province of the Gulf of Mexico (Basáñez 2005). This site contains the four species of mangrove that are distributed in Mexico, all of which are found under the category of special protection: Avicennia germinans (L.) L. (black mangrove), Conocarpus erectus L. (buttonwood mangrove), Laguncularia racemosa (L.) C. F. Gaertn (white mangrove), and Rhizophora mangle L. (red mangrove) (Basáñez 2005).

\section{Study species}

M. grandiflora (Lindl.) Carnevali, J.L. Tapia \& I. Ramírez. it has purple-lilac or lilac-orange flowers, with quite wide and flat petals, the labellum is very open and the inflorescences are long and simple (Carnevali 2009). The production of its scent increases throughout the morning (Parra-Tabla et al. 2009). It is known as the ant orchid, since it is associated with ants that inhabit the interior of the pseudobulb hollows. It is endemic to Mexico, occurring in the states of Veracruz, Chiapas and Oaxaca, and is generally epiphytic (Carnevali et al. 2003). Given the aforementioned characteristics (daytime production of scent, color and shape of flowers), the expected pollination syndrome corresponds to bees (Rico-Gray and Thien 1987, Faegri and Van Der Pijl 2013). B. nodosa (L.) Lindl. is an epiphytic species, known as the "lady of the night" because it releases a characteristic nocturnal fragrance (Jones 1975); its flowers are white, $9-15 \mathrm{~cm}$ in diameter (Mahr, 2004). Geographically, it is distributed throughout southeastern Mexico, Central America and the northern part of Colombia. It can be found growing on tree trunks and branches in lowland tropical forests and mangrove swamps, or on bare rocks and cliffs by the seashore (Schemske 1980, Murren and Ellison 1998, NogueraSavelli 2010). Given the aforementioned characteristics (fragrance, nocturnal activity and white flowers), the expected pollination syndrome would correspond to moths (Schemske 1980, Faegri and Van Der Pijl 2013).

\section{Floral visitors and pollinators}

To identify pollinators and floral visitors, we conducted trips to the RAMSAR site number 1602 during the period of March to July 2012, which corresponds to the flowering period of the studied species, attempting to cover its entire local range (Figure 1). Times for visitor observations and recordings were chosen considering the reproductive biology of $M$. grandiflora and $B$. nodosa, diurnal and nocturnal, respectively (Roebuck and Steinhart 1978, Parra-Tabla and Vargas 2004). Thus, in M. grandiflora, sampling was from 07:00 to 12:00 hours and in B. nodosa, from 21:00 to 01:00 hours. We conducted focal observations for $10 \mathrm{~min}$ in one individual flower (one meter away) and then moved to another flower to repeat the sampling procedure. This strategy was used in order to maximize sampling throughout the entire area. Binoculars (Mizar MR- de $10 \times 50 \mathrm{~mm}$ ) were used and images captured with a photographic camera (Canon EOS).

During observations, all visitors that arrived at the flowers of both orchid species were recorded. We considered a visitor any individual that landed 


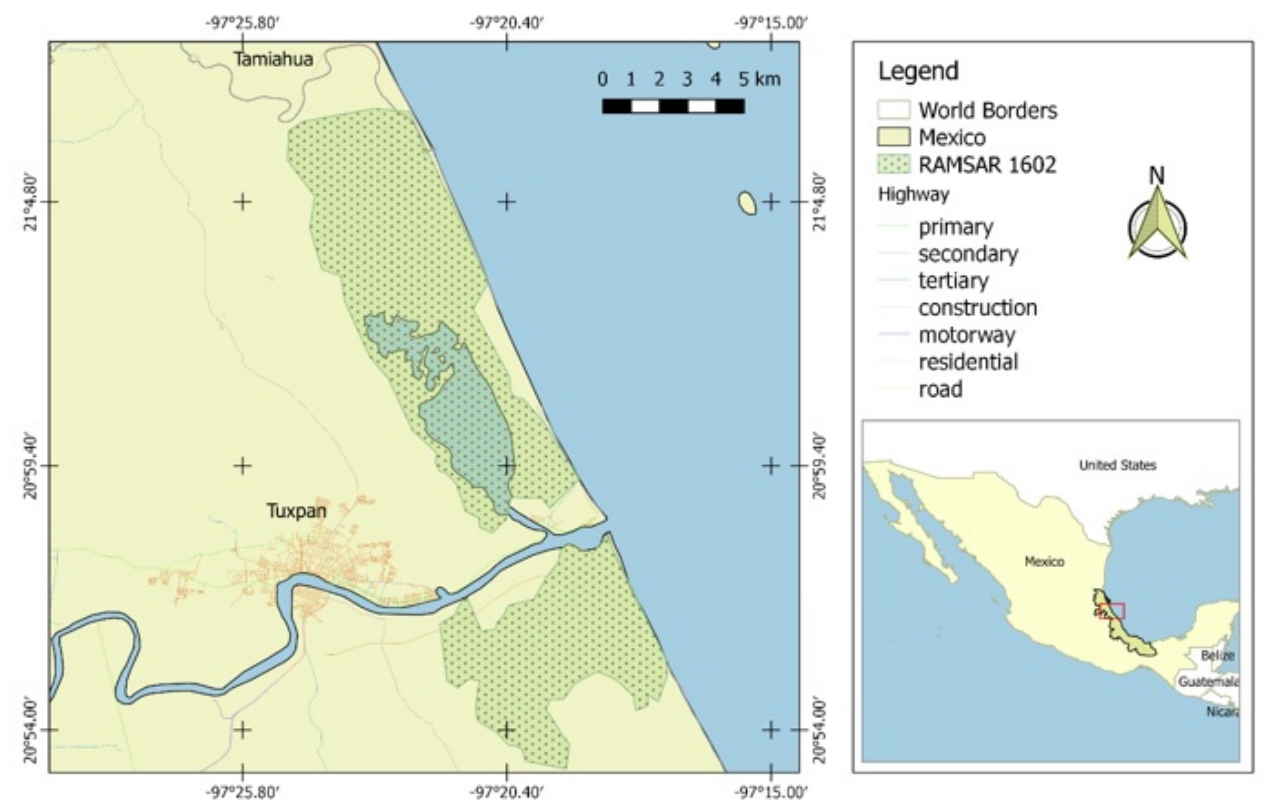

Figure 1. Study site, protected area RAMSAR 1602, Tuxpan, Veracruz, Mexico.

on the flower, and a pollinator when pollen was visibly attached and moved towards other flowers. Following field observations, all visitors were captured in plastic jars for examination in the laboratory under a stereoscopic microscope (Nikon, C-PS). The collected insects were deposited in the entomological collection of the Faculty of Biology and Agronomy, Tuxpan, Veracruz. Determination of species was carried out using identification guides (Delvare et al. 2002, Eaton and Kaufman 2007) and consulting experts.

\section{RESULTS AND DISCUSSION}

\section{Host trees (phorophytes)}

We recorded 54 flowers of the orchid $M$. grandiflora (30 hours of observation) and 14 flowers of $B$. nodosa (24 hours of observation), all of them growing on the stem of adult trees of $C$. erectus, $L$. racemosa and $R$. mangle. Both orchid species have been reported inhabiting coastal ecosystems, mainly mangroves (Schemske 1980, López Portillo and Ezcurra 2002). According to Murren and Ellison (1998), in coastal Belize, red, black, and white mangroves are the most common host trees of $B$. nodosa, however, despite being present, they did not observe the establishment of $B$. nodosa in $C$. erectus. On the Yucatan peninsula, interactions with two species have been reported for $M$. tibicinis: the red mangrove ( $R$. mangle) and the black mangrove (A. germinans) (Rico-Gray and Thien 1987, Rico-Gray 1989). It is remarkable that despite the presence of four mangrove species, we did not register any orchids in $A$. germinans, However, Dejean et al. (2003) reported the growth of M. christinae (closely related and similar in many ecological attributes to M. grandiflora) in A. germinans. It would be worth exploring such differences in detail, bearing in mind that it is also possible that these hosts exhibit generalist interactions with Myrmecophila orchids, as noted in recent reviews (Wagner et al. 2015).

\section{Floral visitors}

The floral visitors of $M$. grandiflora were three species of ants, belonging to the genera Crematogaster, Camponotus and Pseudomyrmex, which were observed numerous times crossing the flowers (Table 1). The floral visitors of $B$. nodosa were mosquitoes belonging to the family Culicidae (Diptera), as well as 
ladybugs (Coleoptera: Coccinellidae, Table 1). As the genus name suggests (Myrmecophila literally means "ant loving"), the floral visitors of $M$. grandiflora were mainly ants (Table 1). The same pattern has been observed in $M$. tibicinis and $M$. christinae, where there is an association ant-orchid in which extrafloral nectar is produced by the inflorescence and is collected by the ants. In return, they occupy the hollow pseudobulbs and defend the inflorescences and the phorophytes from herbivory (Rico-Gray 1989, Malo et al. 2001, Dejean et al. 2003).

The species $M$. tibicinis has been observed interacting with 8 to 13 species of ants on the Yucatan peninsula (Rico-Gray and Thien 1987, Thien et al. 1987). For M. grandiflora, in contrast, we recorded 109 individual visitors of three genera of ants; it is possible that there are several species per genera, but it was not possible to identify ants at species level. In our study, unlike $M$. grandiflora, visitors to $B$. nodosa, were scarce. This feature seems common within this genus, as suggested by the scarce data on pollinators reported by previous studies. Rech et al. (2010) only observed the bee Plebeia remota visiting $B$. cebolleta. In Brazil, hummingbirds (Trochilidae) were observed visiting flowers of $B$. martiana and $B$. tuberculate (Braga 1977, Van Der Cingel 2001). It is possible that by presenting a phalaenophily syndrome, the attraction of pollinators and floral visitors, is very restricted and specific to certain times of night. A possible solution to the lack of information, could contemplate observations for a longer time. Since our study only evaluated four hours at night, it is possible that interactions with other species are performed at other times that were not contemplated here. In this sense, Damon and Salas-Roblero (2007) show in Chiapas, Mexico, that several species of Lepidoptera were observed visiting flowers of $B$. nodosa during the day.

\section{Pollinators}

In our study, the pollination of $M$. grandiflora was entomophilous, carried out by the female carpenter bee Xylocopa nautlana Cockerell (Figure 2A). Pollination was achieved using the thorax, on which up to eight pollinia were carried (Figure 2B, Table 1).
This evidence is important, not only because the pollinator of $M$. grandiflora was hitherto unknown, but also because it reinforces the information regarding pollinators of this genus, i.e., that they are pollinated by bees, which are considered to pollinate around $60 \%$ of the orchids (Pijl and Dodson 1966). For example, $M$. tibicinis and M. christinae, species closely related (Carnevali et al. 2003) and distributed in similar environments, are pollinated by Eulaema polychroma Mocsáry and another species of the genus Xylocopa (Rico-Gray and Thien 1987, Parra and Nates-Parra 2007).

The genus Brassavola is assumed to be mothpollinated. This idea is based on some of the characteristics associated with a sphingophilous pollination syndrome (Lepidoptera: Sphingidae), the production of a nocturnal, strongly sweet but not fruity floral scents, size, morphology and the presence of a cream or white flower color (Roebuck and Steinhart 1978, Williams 1981). In our study, no pollinator was observed for $B$. nodosa during field trips; however, we observed a recurring visitor, a white moth (Geometridae) Scopula sp. (Figure 2 C, D, Table 1), which is a genus observed previously by other authors. Pijl and Dodson (1966) reported a sphingid moth as the potential pollinator of $B$. nodosa. Schemske (1980) refers in his study to a white moth as a pollinator; and more recently, Damon and Salas-Roblero (2007) observed a sphingid moth at any time of day. Nevertheless, these authors neither recorded any evidence of pollination. Likewise, in B. cebolleta, a moth of the family Notodontidae, was recorded as a potential pollinator because pollination could not be observed directly (Rech et al. 2010). Finally, it should be noted that, while the pollinator was not recorded, we did observe the occurrence of fructification, which would indicate the presence of pollinators at the site, pointing the need to explore with greater attention the pollination of this species.

In our study, we identified the pollinator of the orchid M. grandiflora in the area of Tuxpan, Veracruz, Mexico, which was the carpenter bee $X$. nautlana. We could not identify the pollinator of $B$. nodosa; however, it is possible that it could be a moth, considering that this insect was frequently observed and fits the polli- 
Table 1. Floral visitors and pollinators of the two study species in Tuxpan, Veracruz, Mexico. In asterisk the pollinator.

\begin{tabular}{|c|c|c|}
\hline Orchid & $\begin{array}{l}\text { Floral Visitor } \\
\text { Family: Genus species }\end{array}$ & $\begin{array}{l}\text { Number of } \\
\text { visits }\end{array}$ \\
\hline \multirow{5}{*}{$\begin{array}{l}\text { Myrmecophila grandiflora (Lindl.) } \\
\text { Carnevali \& J.L.Tapia \& I.Ramírez }\end{array}$} & Apidae: Xylocopa nautlana Cockerell ${ }^{*}$ & 33 \\
\hline & Formicidae: Crematogaster & 45 \\
\hline & Formicidae: Camponotus & 37 \\
\hline & Formicidae: Pseudomyrmex & 27 \\
\hline & Salticidae & 4 \\
\hline \multirow{3}{*}{ Brassavola nodosa (L.) Lindl. } & Coccinellidae & 3 \\
\hline & Culicidae & 6 \\
\hline & Geometridae: Scopula* & 14 \\
\hline
\end{tabular}

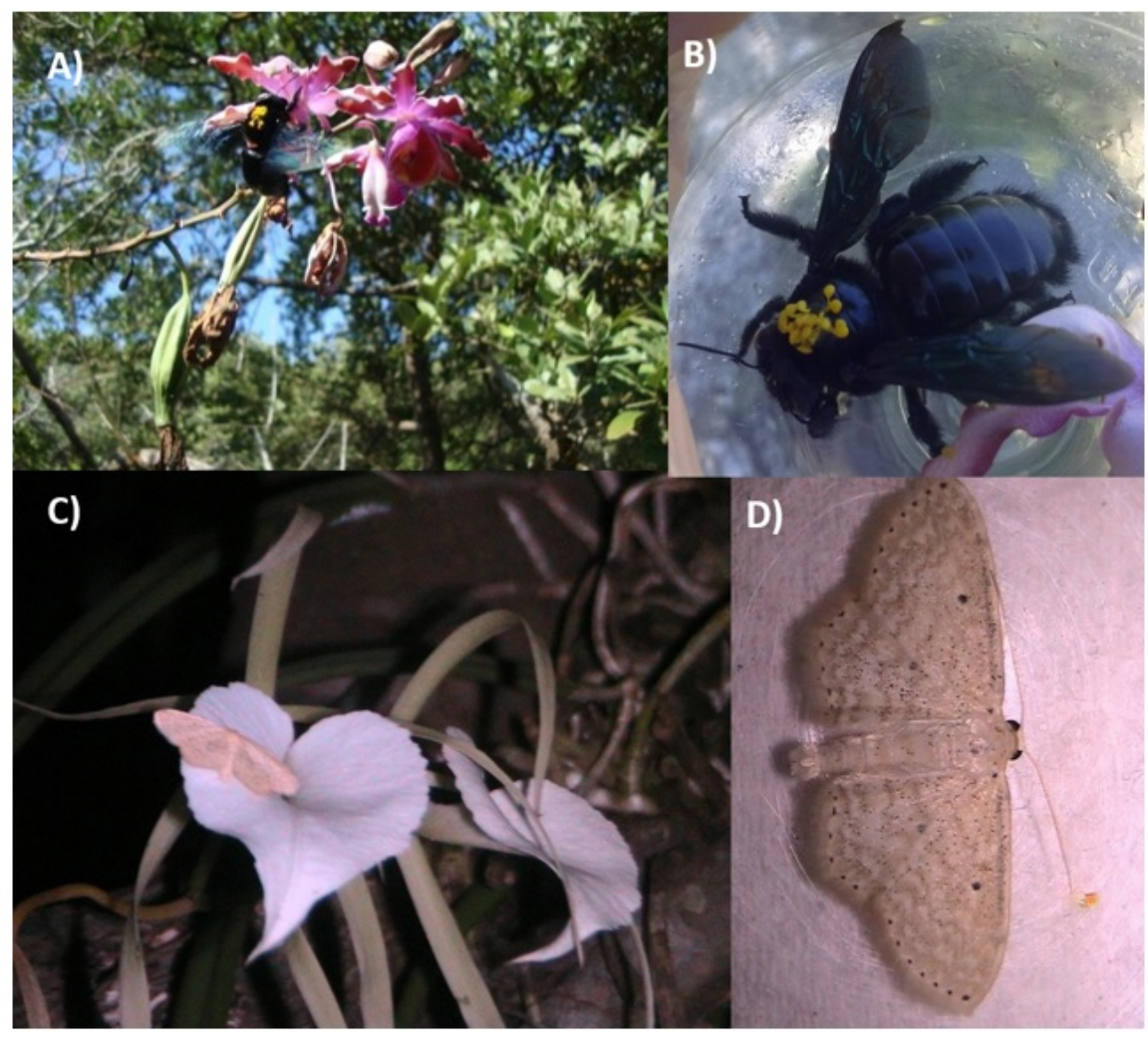

Figure 2. A) Xylocopa nautlana, with polinia of Myrmecophila grandiflora; B) X. nautlana; C and D) Scopula sp. (Geometridae) visiting Brassavola nodosa.

nation syndrome of this orchid. Future studies should identify whether the ecological condition of sites under environmental protection truly favor plant reproduction. Further, they should provide quantitative data regarding the number of floral visitors and their relationship with the adaptation of the orchids that grow in mangrove ecosystems. Finally, future studies should propose strategies to record and identify the pollinator of $B$. nodosa.

\section{ACKNOWLEDGEMENTS}

This study is part of the bachelor dissertation of Ortiz Santos LC and was supported by a Master's Thesis scholarship by CONACyT. Limón F thanks the Master of Environmental Sciences of the Universidad Veracruzana and National Council on Science and Technology (CONACyT) for a postdoctoral scholarship (2018-2019). We thank Dr. Ricardo 
Ayala Barajas for the identification of the Xylocopa bee. Dr. Jonas Morales-Linares, for his comments on the preliminary version of this text and to the edi- tor and the two anonymous reviewers who helped improve the quality of the manuscript.

\section{LITERATURE CITED}

Ames O, Correll DS (1985) Orchids of Guatemala and Belize. Courier Corporation. USA. 779p.

Basáñez MAJ (2005) Ficha informativa de los humedales de Ramsar. Manglares y humedales de Tuxpan, sitio Ramsar Internacional 1602. Ramsar Sites Information Service. 12p.

Braga PIS (1977) Aspectos biológicos das Orchidaceae de uma campina da Amazônia Central. Acta Amazonica 7: 1-89

Carnevali G (2009) La falsa tibicinis, la hermana de cristina la yucateca: Myrmecophila grandiflora. Desde el Herbario CICY 1: 26-27.

Carnevali GC, Muñoz JLT, Ramírez IM (2001) The Status of Schomburgkia tibicinis var. grandiflora Lindl. (Orchidaceae) and a Key to the Mexican Species of Myrmecophila. Harvard Papers in Botany 6: 245-251.

Carnevali G, Tapia JL, Williams NH, Whitten WM (2003) Sistemática, filogenia y biogeografía de Myrmecophila. Lankesteriana 7: 29-32.

Damon A, Salas-Roblero P (2007) A survey of pollination in remnant orchid populations in Soconusco Chiapas, Mexico. Tropical Ecology 48: 1-14.

Dejean A, Durou S, Olmsted I, Snelling RR, Orivel J (2003) Nest site selection by ants in a flooded Mexican mangrove, with special reference to the epiphytic orchid Myrmecophila christinae. Journal of Tropical Ecology 19: 325-331.

Delvare G, Aberlenc HP, Michel B (2002) Los insectos de África y de América tropical claves para la identificación de las principales familias. CIRAD - Centre De Coopération Internationale En Recherche A Gronomique Pour Le Développement. Montpellier, France. 257p.

Eaton ER, Kaufman K (2007) Kaufman field guide to insects of North America. Houghton Mifflin Harcourt. USA. $391 p$.

Faegri K, Van Der Pijl L (2013) Principles of pollination ecology. 3ed. Pergamon Press Ltd. UK. 256p.

García-Cruz CJ, Sosa V (2011) Las orquídeas. In: Cruz-Angón A (ed). La Biodiversidad en Veracruz, estudio de estado. Vol. II. Comisión Nacional para el Conocimiento y Uso de la Biodiversidad, Gobierno del Estado de Veracruz, Universidad Veracruzana, Instituto de Ecología. México. pp: 191-199.

Hágsater E, Dumont V, Pridgeon AM (1996) Orchids: status survey and conservation action plan, Volume 28. IUCN. Gland, Suiza. 153p.

Hágsater E, Soto-Arenas MA, Salazar-Chávez GA, Jiménez-Machorro R, López-Rosas MA, Dressler RL (2005) Las orquídeas de México. Instituto Chinoín. México. 304p.

Herrera CM (1987) Components of pollinator "quality": comparative analysis of a diverse insect assemblage. Oikos 9: 79-90.

Horvitz CC, Schemske DW (1990) Spatiotemporal variation in insect mutualists of a neotropical herb. Ecology 71: 1085-1097.

INEGI (2010) Tuxpan, Veracruz de Ignacio de la Llave. Clave geoestadística 30189, Prontuario ed. Instituto Nacional de Geografía y Estadística. México. 212p. 
Jones HG (1975) Nomenclatural revision of the genus Brassavola R. Br. of the Orchidaceae. Annalen des Naturhistorischen Museums in Wien 32: 9-22.

Lee SY, Primavera JH, Dahdouh-Guebas F, McKee K, Bosire JO, Cannicci S, et al. (2014) Ecological role and services of tropical mangrove ecosystems: a reassessment. Global Ecology and Biogeography 23: 726743.

López Portillo J, Ezcurra E (2002) Los manglares de México: una revisión. Madera y Bosques 2: 27-51.

Mahr S, (2004) Lady of the Night Orchid, Brassavola nodosa. Wisconsin Master Gardener. University of Wisconsin-Madison USA. https://wimastergardener.org/files/2015/12/Brassavola_nodosa.pdf Recovered: November 16, 2018.

Malo JE, Leirana-Alcocer J, Parra-Tabla V (2001) Population fragmentation, florivory, and the effects of flower morphology alterations on the pollination success of Myrmecophila tibicinis (Orchidaceae). BIOTROPICA 33: 529-534.

Murren C, Ellison A (1998) Seed dispersal characteristics of Brassavola nodosa (Orchidaceae). American Journal of Botany 85: 675-679.

Noguera-Savelli E (2010) Revisión del género Brassavola R. Br. (Orchidaceae) para Venezuela. Ernstia 20: 169-192.

Parra-Tabla V, Abdala-Roberts L, Rojas JC, Navarro J, \& Salinas-Peba L. (2009). Floral longevity and scent respond to pollen manipulation and resource status in the tropical orchid Myrmecophila christinae. Plant Systematics and Evolution 282: 1-11.

Parra-Tabla V, Vargas CF (2004) Phenology and phenotypic natural selection on the flowering time of a deceitpollinated tropical orchid, Myrmecophila christinae. Annals of Botany 94: 243-250.

Parra A, Nates-Parra G (2007) Variación de la comunidad de abejas de las orquídeas (Hymenoptera: Apidae) en tres ambientes perturbados del piedemonte llanero colombiano. Revista de Biología Tropical 55: 931-941.

Pellegrino G, Bellusci F, Musacchio A (2010) The effects of inflorescence size and flower position on female reproductive success in three deceptive orchids. Botanical Studies 51: 351-356.

Pijl LVD, Dodson CH (1966) Orchid flowers: their pollination and evolution. Published jointly by the Fairchild Tropical Garden and the University of Miami Press, USA. 242p.

RAMSAR (2016) Manglares y humedales de Tuxpan. Ramsar Sites Information Service. México. 12p.

Rech AR, Rosa YBCJ, Manente-Balestieri FC de L (2010) Aspects of the reproductive biology of Brassavola cebolleta Rchb. f. (Orchidaceae). Acta Scientiarum Biological Sciences 32: 335-341.

Rico-Gray V (1989) The importance of floral and circum-floral nectar to ants inhabiting dry tropical lowlands. Biological Journal of the Linnean Society 38: 173-181.

Rico-Gray V, Thien LB (1987) Some aspects of the reproductive biology of Schomburgkia tibicinis Batem (Orchidaceae) in Yucatan, Mexico. Brenesia 28: 13-24.

Roebuck L, Steinhart WL (1978) Pollination ecology and the nocturnal scent response in the genus Brassavola. American Orchid Society Bulletin 47: 507-511.

Schemske DW (1980) Evolution of floral display in the orchid Brassavola nodosa. Evolution 35: 489-493.

Schiestl FP (2005) On the success of a swindle: pollination by deception in orchids. Naturwissenschaften 92 : 255-264. 
Thien LB, Rico-Gray V, Smalley AE, Bradburn AS (1987) Complexity of tropical rain forests. Tulane Studies in Zoology and Botany. 26: 5-18.

Van Der Cingel (2001) An Atlas of Orchid Pollination: America, Africa, Asia and Australia. CRC Press. New Jersey, USA. 260p.

Wagner K, Mendieta-Leiva G, Zotz G (2015) Host specificity in vascular epiphytes: A review of methodology, empirical evidence and potential mechanisms. AoB Plants 7: plu092. DOI:10.1093/aobpla/plu092.

Williams NH (1981) Floral fragrance components of Brassavola (Orchidaceae: Laeliinae). Selbyana 5: 279-285. 